\title{
Nutritional and physical requirements for mycelial growth and fruiting body production of six strains of Pleurotus djamor from Luzon Island, Philippines
}

Sofronio P. Kalaw ${ }^{1,2}$, Rich Milton R. Dulay, ${ }^{1,2}$, Eduardo J. Damaso Jr. ${ }^{1}$, Joshua C. Ramos ${ }^{1}$, Mark Adrian G. del Rosario', Marcelino D. Abon'1, Angeles M. De Leon ${ }^{1,2}$, Renato G. Reyes ${ }^{1,2}$

${ }^{1}$ Tuklas Lunas Development Center, Central Luzon State University, Science City of Muñoz, Nueva Ecija, Philippines 3120

${ }^{2}$ Department of Biological Sciences, College of Science, Central Luzon State University, Science City of Muñoz, Nueva Ecija, Philippines 3120

\begin{tabular}{|c|c|}
\hline 2021 & \multirow[b]{4}{*}{ 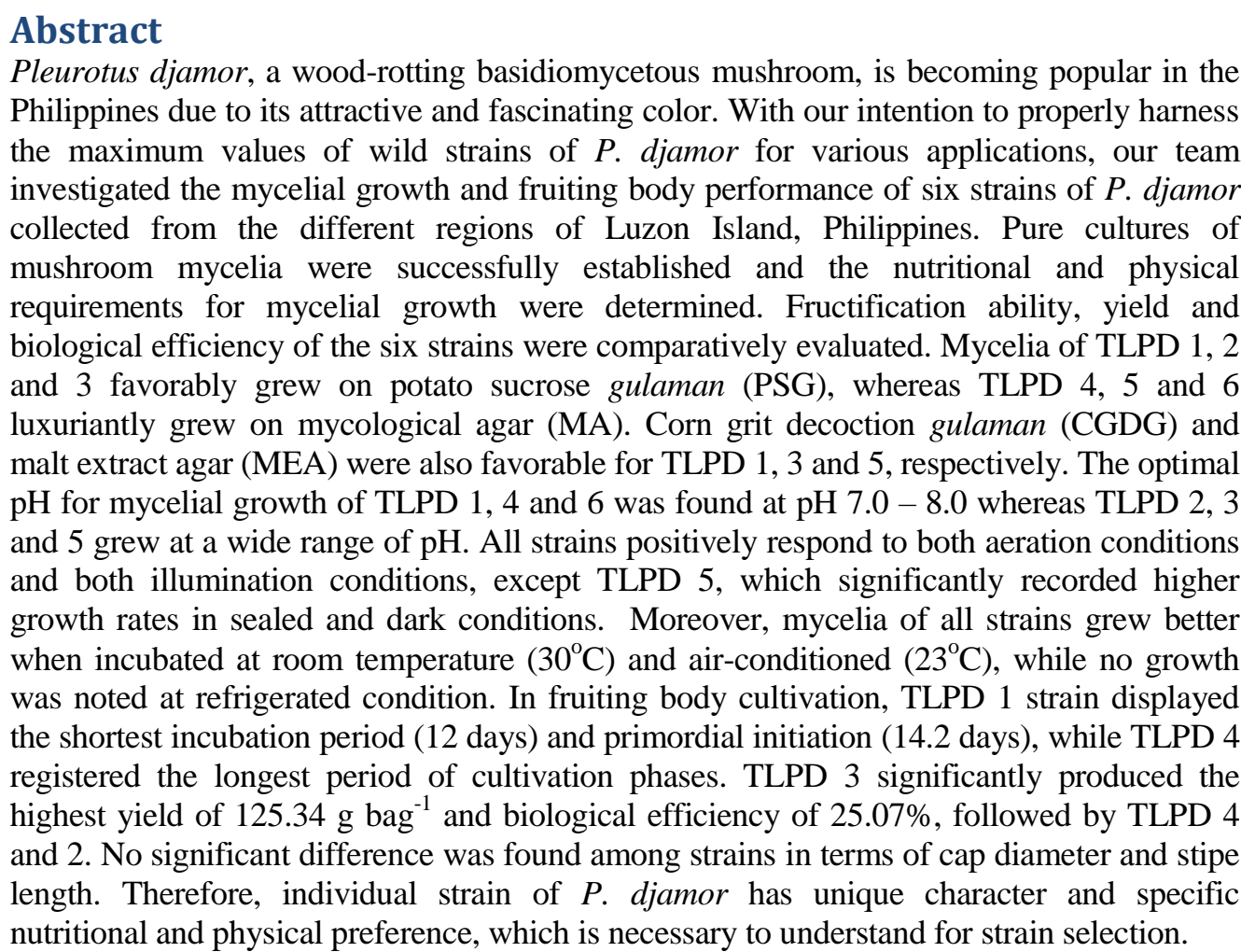 } \\
\hline $\begin{array}{l}\text { Accepted: } \\
\text { November 20, } 2021\end{array}$ & \\
\hline $\begin{array}{l}\text { Online First: } \\
\text { February 11, } 2022\end{array}$ & \\
\hline $\begin{array}{l}\text { Published: } \\
\text { June 06, } 2022\end{array}$ & \\
\hline & $\begin{array}{l}\text { Keywords: Pleurotus djamor strains, Mycelial growth, Fructification, Nutritional } \\
\text { requirements, Physical factors }\end{array}$ \\
\hline & $\begin{array}{l}\text { How to cite this: } \\
\text { Kalaw SP, Dulay RMR, Damaso Jr. EJ, Ramos JC, del Rosario MAG, Abon MD, De } \\
\text { Leon AM, and Reyes RG, 2022. Nutritional and physical requirements for mycelial } \\
\text { growth and fruiting body production of six strains of Pleurotus djamor from Luzon }\end{array}$ \\
\hline $\begin{array}{l}\text { *Corresponding author email: } \\
\text { richmiltondulay@clsu.edu.ph }\end{array}$ & $\begin{array}{l}\text { Island, Philippines. Asian J. } \\
\text { https://doi.org/10.35495/ajab.2021.05.233. }\end{array}$ \\
\hline & \\
\hline
\end{tabular}




\section{Introduction}

Macrofungi, also called macroscopic fungi, are those producing fruiting bodies that are visible to the naked eye (Tang et al., 2015). They are achlorophyllus, eukaryotic, heterotrophic organisms that obtain their nourishment by absorption and reproduce by means of spores. This group includes mushrooms, puffballs, hoofed fungi, coral fungi and other large types of fungi (Torres et al., 2020), which belong to Basidiomycetes and Ascomycetes. Mushrooms usually thrive in moist environment particularly on decomposing lignocellulosic materials such as leaves and stems, animal dung, logs, twigs, damp soils, etc. They play different roles in the ecosystem in which majority of them are decomposers and saprophytes while some are parasites and others form mutualistic association with other organisms (Reyes et al., 2009). Mushrooms have been an important source of biologically active compounds, which can be exploited in the nutraceutical and pharmaceutical industry. Several bioactive compounds with medicinal properties have been isolated from different species of mushrooms. For instance, lentinan, a polysaccharide derived from Lentinula edodes is used in the treatment of cancer in China and Japan (Zhang et al., 2019). Schizophyllan from Schizophyllum commune significantly inhibits the growth of rat CNS-1 glioma cells in vitro, induces apoptosis, and blocks the cell cycle (Zhou et al., 2015). Moreover, Li et al. (2005) reported that ganoderic acid X obtained from Ganoderma lucidum inhibits topoisomerases and sensitizes the cancer cells toward apoptosis.

In this regard, it is of our desire to develop drugs and functional food derived from Philippine native mushroom species. Thus, our research team collected naturally-occurring mushrooms from different areas of Luzon Island, Philippines. In our mycological expeditions, we have collected several strains of Pleurotus djamor (Rumph. ex Fr.) Boedijn. P. djamor is an oyster, basidiomycetous edible wood rotting mushrooms with high nutritional value and medicinal properties. The fruiting bodies of this mushroom contain ergosterol, triacylglycerols, fatty acids methyl esters, which are reported to be responsible for antitumor and antioxidant properties (Ragasa et al., 2016). It also possesses nematocidal metabolites, which can be used as an alternative antihelminthic (Pineda-Alegria et al., 2017). This mushroom also contains anthraquinones, flavonoids, saponins, tannins and terpenoids (Sasidhara and Thirunalasundari, 2014). Likewise, galactoglucan, which exhibits antioxidant activity, is also found in this mushroom (Maity et al., 2021).

In the present study, we evaluated the optimal cultural conditions of the six strains of $P$. djamor in order to establish their cultivation potential, which is necessary for the exploration of their benefits and advantages. The influence of nutritional and physical factors on mycelial growth of six strains of $P$. djamor was evaluated. The fruiting body production using rice straw and sawdust-based substrate formulation in growing house condition was also investigated.

\section{Material and Methods}

\section{Isolation of secondary mycelia}

Fruiting bodies of six wild strains P. djamor (Figure 1) were collected from their natural habitat in the different areas in Luzon Island. Mushrooms were brought to the Center for Tropical Mushroom Research and Development laboratory for tissue culture in order to acquire the secondary mycelia. Briefly, approximately $10 \mathrm{~mm}^{2}$ tissue was aseptically cut from inner portion of the fruiting body using sterile scalpel and subsequently inoculated onto sterilized potato dextrose agar. Cultures were incubated at room temperature to allow mycelial growth. After 7 days, mycelia were sub-cultured onto PDA plate, which served as the source of inocula.

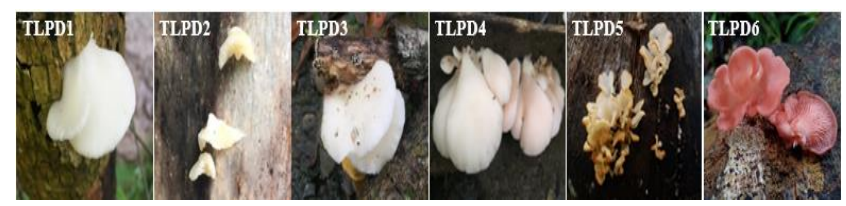

Figure-1: Wild fruiting bodies of Pleurotus djamor on their natural substrates collected from Sugpon, Ilocos Sur (TLPD1), Alilem, Ilocos Sur, (TLPD2 and TLPD3), CLSU (TLPD4), Lukong Valley, Dolores, Quezon (TLPD5) and Pili, Camarines Sur (TLPD6)

\section{Evaluation of culture media and $\mathbf{p H}$}

The mycelial growth of six strains of $P$. djamor was evaluated using four indigenous culture media and four commercial dehydrated media. The commercial media such as potato dextrose agar (PDA), malt extract agar (MEA), sabouraud dextrose agar (SDA) and mycological agar (MA) were prepared following the manufacturer's recommendation. However, the indigenous culture media namely: coconut water gulaman (CWG), rice bran decoction gulaman 
(RBDG), corn grit decoction gulaman (CGDG) and potato sucrose gulaman (PSG) were prepared following the protocol of Kalaw et al. (2016). Culture media were sterilized at $121^{\circ} \mathrm{C}, 15 \mathrm{psi}$ for $30 \mathrm{~min}$. After sterilization, culture media were cooled down and poured into a sterilized petri dish and allowed to solidify for 24 hours. A $10 \mathrm{~mm}$ diameter mycelial disc was inoculated to the center of the plates and incubated at room temperature. Triplicate plates were used per culture medium. The mycelial growth and mycelial density were determined. After culture media evaluation, the influence of $\mathrm{pH}$ was determined by culturing the mycelia at different $\mathrm{pH}$ such as 5.0, 5.5, 6, 6.5, 7.0, 7.5 and 8 using the best culture medium.

\section{Evaluation of physical conditions}

Apart from media evaluation, the effect of different physical factors such as aeration, illumination and temperature were also determined following the procedures described by Kalaw et al. (2016). To determine the influence of aeration, the culture plates were sealed with parafilm while the other plates remained unsealed. On the other hand, in the assessment of illumination, two conditions such as dark and lighted were used. In lighted conditions, the inoculated plates were exposed to artificial light (322.92 lumens $\mathrm{m}^{-2}$ white light of fluorescent lamp) by incubating the plates in a chamber while in dark conditions the inoculated culture plates were wrapped with carbon paper. Finally, the influence of temperature was determined by incubating the inoculated plates in room temperature $\left(32^{\circ} \mathrm{C}\right)$, air-conditioned room $\left(23^{\circ} \mathrm{C}\right)$ and refrigerated $\left(9^{\circ} \mathrm{C}\right)$ conditions. Triplicate plates were used per treatment. The mycelial growth and mycelial density were determined.

\section{Evaluation of fruiting body production}

The basidiocarp was produced using the 7 parts of rice straw and 3 parts of sawdust (v/v) based substrate formulation developed by Center for Tropical Mushroom Research and Development. Approximately $750 \mathrm{~g}$ of formulated substrates were compacted in a $6 \times 12 \times 0.03$-inch polypropylene bags. Five bags were prepared for each strain. The bagged substrates were autoclaved for 1 hour. After sterilization, the fruiting bags were allowed to cool down overnight. Each bag was inoculated with $40 \mathrm{~g}$ of grain spawn and incubated at room temperature. When the fruiting bags were fully ramified with mycelia, they were transferred to the growing house.
One side of the fruiting bags was opened and sprinkled with water three time a day to initiate the appearance of fruiting bodies. The number of days to full mycelial colonization of the substrates was recorded. All the fruiting bodies were harvested and the percentage biological efficiency was determined by dividing the total weight of the fruiting bodies by total weight of the substrate multiplied by 100 .

\section{Statistical analysis}

The experiment was laid out following the completely randomized design. All pertinent data were analyzed using SAS computer program. Means were compared using Tukey's HSD at $5 \%$ level of significance.

\section{Results}

\section{Culture media}

The culture medium contains the essential nutrients needed by the mushroom mycelia for normal growth and development. The luxuriant mycelial growth depends on the nutritional content of the medium where they are cultured. Thus, identification of suitable culture media is essential for mushroom cultivation. In the present study, four indigenous culture media and four commercial dehydrated media were evaluated for the mycelial growth of six $P$. djamor strains. The mycelial growth rates of the six strains are presented in Table 1. It can be seen that all culture media were found suitable for the mycelial growth of the six strains. However, TLPD 1, 2 and 3 exceedingly favored PSG, whereas TLPD 4, 5 and 6 exceedingly favored MA as indicated by faster mycelial growth and thick mycelial density. CGDG and MEA were also favorable for TLPD 1, 3 and 5, respectively. Fast mycelial growth of TLPD 6 was also noted in PDA, MEA, SDA and PSG. It is interesting to note that the first three strains preferred indigenous culture media, whereas the last three favored dehydrated culture media.

\section{pH}

Aside from culture media, the $\mathrm{pH}$ of the medium is also an important factor in mushroom production. To find out the optimum $\mathrm{pH}$ for the mycelial growth, the six strains of $P$. djamor were cultured on the most suitable media at varying $\mathrm{pH}$ levels (5.0 to 8.0 with 0.5 interval). The mycelial growth rates of the six strains as affected by $\mathrm{pH}$ are also presented in Table 1 . Variation in mycelial growth response was observed 
among different strains. TLPD 2, 3 and 5 mycelia grew best at a wider $\mathrm{pH}$ range of 5-8, while TLPD 1, 4 and 6 displayed faster mycelial growth at $\mathrm{pH} 7-8$. All strains exhibited thick to very mycelial growth.

\section{Aeration}

To determine the influence of aeration on mycelial growth of six strains of $P$. djamor, the mycelia were cultured in sealed and unsealed conditions. The mycelial growth rates of the six strains as influenced by aeration conditions are shown in Table 1 . It can be noticed that the mycelial growth of all strains, except TLPD 5, in two aeration conditions was not significantly different, suggesting the suitability both conditions for mycelial growth. On the other hand, TLPD 5 showed faster mycelial growth in sealed condition.

Table-1: Effect of culture media, pH, aeration, illumination and temperature on the mycelial growth of the six strains of Pleurotus djamor.

\begin{tabular}{|c|c|c|c|c|c|c|}
\hline \multirow{3}{*}{ Factors } & \multicolumn{6}{|c|}{ Mycelial growth rate $\left(\right.$ day $\left.^{-1}\right)$} \\
\hline & TLPD & TLPD & TLPD & TLPD & TLPD & TLPD \\
\hline & & & & & & \\
\hline \multicolumn{7}{|l|}{$\begin{array}{c}\text { Culture } \\
\text { media }\end{array}$} \\
\hline CWG & $13.07^{\mathrm{d}}$ & $11.48^{\mathrm{de}}$ & $13.39^{\mathrm{d}}$ & $3.45^{\mathrm{d}}$ & $10.49^{\mathrm{d}}$ & $12.38^{\mathrm{bc}}$ \\
\hline PSG & $18.00^{\mathrm{a}}$ & $18.00^{\mathrm{a}}$ & $18.00^{\mathrm{a}}$ & $10.93^{\mathrm{b}}$ & $15.25^{\mathrm{b}}$ & $14.31^{\mathrm{a}}$ \\
\hline CGDG & $18.00^{\mathrm{a}}$ & $15.48^{\mathrm{b}}$ & $17.85^{\mathrm{a}}$ & $11.43^{\mathrm{b}}$ & $14.54^{\mathrm{bc}}$ & $12.86^{\mathrm{b}}$ \\
\hline RBDG & $15.68^{b}$ & $14.68^{\mathrm{bc}}$ & $15.10^{\mathrm{b}}$ & $8.92^{\mathrm{c}}$ & $12.88^{\mathrm{c}}$ & $11.89^{\mathrm{c}}$ \\
\hline PDA & $13.66^{\mathrm{d}}$ & $11.68^{\mathrm{d}}$ & $13.43^{\mathrm{d}}$ & $11.16^{\mathrm{b}}$ & $13.63^{\mathrm{bc}}$ & $14.09^{\mathrm{a}}$ \\
\hline MEA & $14.74^{c}$ & $9.09^{\mathrm{e}}$ & $10.12^{\mathrm{f}}$ & $11.53^{\mathrm{b}}$ & $17.88^{\mathrm{a}}$ & $14.70^{\mathrm{a}}$ \\
\hline SDA & $14.93^{c}$ & $11.28^{\mathrm{de}}$ & $12.62^{\mathrm{e}}$ & $10.24^{\mathrm{bc}}$ & $15.23^{\mathrm{b}}$ & $14.45^{\mathrm{a}}$ \\
\hline MA & $15.81^{b}$ & $12.49^{\mathrm{cd}}$ & $14.36^{\mathrm{c}}$ & $15.00^{\mathrm{a}}$ & $18.00^{\mathrm{a}}$ & $14.86^{\mathrm{a}}$ \\
\hline \multicolumn{7}{|l|}{ pH } \\
\hline 5.0 & $19.31^{\mathrm{c}}$ & $17.67^{\mathrm{b}}$ & $17.77^{\mathrm{b}}$ & $12.56^{\mathrm{c}}$ & $18.00^{\mathrm{a}}$ & $14.60^{\mathrm{d}}$ \\
\hline 5.5 & $21.08^{b}$ & $18.00^{\mathrm{a}}$ & $18.00^{\mathrm{a}}$ & $13.53^{\mathrm{c}}$ & $18.00^{\mathrm{a}}$ & $15.25^{\mathrm{cd}}$ \\
\hline 6.0 & $21.24^{\mathrm{b}}$ & $18.00^{\mathrm{a}}$ & $18.00^{\mathrm{a}}$ & $12.34^{\mathrm{c}}$ & $18.00^{\mathrm{a}}$ & $15.50^{\mathrm{c}}$ \\
\hline 6.5 & $21.48^{\mathrm{b}}$ & $18.00^{\mathrm{a}}$ & $18.00^{\mathrm{a}}$ & $15.63^{\mathrm{b}}$ & $18.00^{\mathrm{a}}$ & $16.41^{\mathrm{b}}$ \\
\hline 7.0 & $22.31^{\mathrm{a}}$ & $18.00^{\mathrm{a}}$ & $18.00^{\mathrm{a}}$ & $16.81^{\mathrm{ab}}$ & $18.00^{\mathrm{a}}$ & $18.00^{\mathrm{a}}$ \\
\hline 7.5 & $22.50^{\mathrm{a}}$ & $18.00^{\mathrm{a}}$ & $18.00^{\mathrm{a}}$ & $16.94^{\mathrm{ab}}$ & $18.00^{\mathrm{a}}$ & $18.00^{\mathrm{a}}$ \\
\hline 8.0 & $22.41^{\mathrm{a}}$ & $18.00^{\mathrm{a}}$ & $18.00^{\mathrm{a}}$ & $18.00^{\mathrm{a}}$ & $18.00^{\mathrm{a}}$ & $18.00^{\mathrm{a}}$ \\
\hline \multicolumn{7}{|l|}{ Aeration } \\
\hline Sealed & $22.50^{\mathrm{a}}$ & $18.00^{\mathrm{a}}$ & $18.00^{\mathrm{a}}$ & $18.00^{\mathrm{a}}$ & $18.00^{\mathrm{a}}$ & $18.00^{\mathrm{a}}$ \\
\hline Unsealed & $22.11^{\mathrm{a}}$ & $18.00^{\mathrm{a}}$ & $18.00^{\mathrm{a}}$ & $17.79^{\mathrm{a}}$ & $15.83^{\mathrm{b}}$ & $18.00^{\mathrm{a}}$ \\
\hline \multicolumn{7}{|l|}{ Illumination } \\
\hline Lighted & $22.50^{\mathrm{a}}$ & $18.00^{\mathrm{a}}$ & $18.00^{\mathrm{a}}$ & $18.00^{\mathrm{a}}$ & $13.25^{\mathrm{b}}$ & $18.00^{\mathrm{a}}$ \\
\hline Dark & $22.50^{\mathrm{a}}$ & $18.00^{\mathrm{a}}$ & $18.00^{\mathrm{a}}$ & $18.00^{\mathrm{a}}$ & $15.00^{\mathrm{a}}$ & $18.00^{\mathrm{a}}$ \\
\hline \multicolumn{7}{|l|}{ Temperature } \\
\hline $9^{\circ} \mathrm{C}$ & $\mathrm{ng}$ & $\mathrm{ng}$ & $\mathrm{ng}$ & $\mathrm{ng}$ & $\mathrm{ng}$ & ng \\
\hline $23^{\circ} \mathrm{C}$ & $21.82^{\mathrm{a}}$ & $18.00^{\mathrm{a}}$ & $17.57^{\mathrm{a}}$ & $17.59^{\mathrm{a}}$ & $15.00^{\mathrm{a}}$ & $18.00^{\mathrm{a}}$ \\
\hline $30^{\circ} \mathrm{C}$ & $22.50^{\mathrm{a}}$ & $18.00^{\mathrm{a}}$ & $18.00^{\mathrm{a}}$ & $18.00^{\mathrm{a}}$ & $15.00^{\mathrm{a}}$ & $18.00^{\mathrm{a}}$ \\
\hline
\end{tabular}

Means with similar superscripts are statistically comparable from each other using Tukeys HSD and t-test at 5\% level of significance. CWG, coconut water gulaman; PSG, potato sucrose gulaman; CGDG, corn grit decoction gulaman; RBDG, rice bran decoction gulaman; PDA, potato dextrose agar; MEA, malt extract agar; SDA, Sabouraud dextrose agar; MA, mycological agar; ng, no growth.

\section{Illumination}

The influence of light was assessed by incubating the inoculated plates under lighted and dark conditions. As seen in Table 1, the mycelial growth of most strains was not significantly affected by the two conditions. However, TLPD 5 strain exhibited faster mycelial growth when incubated in dark condition. With regards to mycelial density, no marked difference was noted between the two conditions. TLPD 4 and 5 produced very thick mycelial density while TLPD 1, 2, 3 and 6 exhibited thick mycelial density in both conditions.

\section{Temperature}

Generally, mushrooms can be classified based on their temperature requirement needed for growth and development namely: temperate, semi temperate and tropical mushroom species. Hence, it is essential to determine the optimum temperature needed for mycelial growth and fruiting body production. In the present study, the temperature requirement for mycelial growth was evaluated by incubating the inoculated plates in three temperature conditions. The mycelial growth response of the different strains is presented in Table 1. No significant difference in mycelial growth and mycelial density was recorded in those incubated at air conditioned $\left(23^{\circ} \mathrm{C}\right)$ and room temperature $\left(30^{\circ} \mathrm{C}\right)$. Noticeably, no mycelial growth was observed in those incubated at refrigerated temperature.

\section{Fruiting body production}

After the evaluation of culture media and physical factors that can influence the mycelial growth of $P$. djamor strains, the fruiting body performance was also assessed using rice straw and sawdust-based formulation developed by the Center for Tropical Mushroom Research and Development. The different cultivation parameters are presented in Table 2 . Among the different strains, TLPD 1 exhibited the shortest incubation period of 12.00 days while TLPD 4 registered the longest incubation period of 27.60 days. In terms of days to primordia initiation, TLPD 6 strain had the shortest period with a mean of 12.4 days while TLPD 4 showed the longest period with a mean of 31.00 days. 
Table-2: Cultivation phases, yield and biological efficiency of six strain of Pleurotus djamor on rice straw and sawdust-based substrate.

\begin{tabular}{|c|c|c|c|c|c|c|}
\hline $\begin{array}{c}\boldsymbol{P} \text {. djamour } \\
\text { strains }\end{array}$ & $\begin{array}{c}\text { Incubation } \\
\text { period } \\
(\mathbf{d a y})\end{array}$ & $\begin{array}{c}\text { Primordia } \\
\text { initiation } \\
(\mathbf{d a y})\end{array}$ & $\begin{array}{c}\text { Cap } \\
\text { diameter } \\
(\mathbf{m m})\end{array}$ & $\begin{array}{c}\text { Stipe } \\
\text { length } \\
(\mathbf{m m})\end{array}$ & $\begin{array}{c}\text { Yield } \\
\left(\mathbf{g ~ b a g}^{-1} \mathbf{)}\right.\end{array}$ & $\begin{array}{c}\text { Biological } \\
\text { efficiency } \\
(\boldsymbol{\%})\end{array}$ \\
\hline TLPD 1 & $12.00^{\mathrm{a}}$ & $14.20^{\mathrm{a}}$ & $51.86^{\mathrm{a}}$ & $10.85^{\mathrm{b}}$ & $91.46^{\mathrm{b}}$ & $18.29^{\mathrm{b}}$ \\
\hline TLPD 2 & $14.60^{\mathrm{b}}$ & $18.70^{\mathrm{b}}$ & $51.53^{\mathrm{a}}$ & $15.82^{\mathrm{a}}$ & $101.66^{\text {ab }}$ & $20.33^{\mathrm{ab}}$ \\
\hline TLPD 3 & $15.10^{\mathrm{b}}$ & $18.40^{\mathrm{b}}$ & $50.67^{\mathrm{a}}$ & $16.97^{\mathrm{a}}$ & $125.34^{\mathrm{a}}$ & $25.07^{\mathrm{a}}$ \\
\hline TLPD 4 & $27.60^{\mathrm{d}}$ & $31.00^{\mathrm{d}}$ & $47.58^{\mathrm{a}}$ & $14.92^{\mathrm{a}}$ & $108.53^{\mathrm{ab}}$ & $21.71^{\mathrm{ab}}$ \\
\hline TLPD 5 & $18.50^{\mathrm{c}}$ & $21.60^{\mathrm{c}}$ & $50.65^{\mathrm{a}}$ & $17.16^{\mathrm{a}}$ & $31.75^{\mathrm{c}}$ & $6.35^{\mathrm{c}}$ \\
\hline TLPD 6 & $18.10^{\mathrm{c}}$ & $12.40^{\mathrm{a}}$ & $47.03^{\mathrm{a}}$ & $16.04^{\mathrm{a}}$ & $48.20^{\mathrm{c}}$ & $10.71^{\mathrm{c}}$ \\
\hline
\end{tabular}

Means with similar superscripts are statistically comparable from each other using Tukeys HSD at 5\% level of significance.

Figure 2 shows the fruiting bodies of $P$. djamor on rice straw and sawdust-based substrate. In cap diameter, no significant difference was found among the six strains. Similarly, no significant difference was also noted in the stipe length of TLPD $2-6$ However, TLPD 1 had the shortest stipe length. In terms of yield and biological efficiency, TLPD 3 strain produced the highest yield of $125.34 \mathrm{~g} \mathrm{bag}^{-1}$ and biological efficiency of $25.07 \%$. However, this was statistically comparable to the yield and biological efficiency exhibited by TLPD 2 and 4. On the other hand, TLPD 5 recorded the lowest yield and biological efficiency with means of $31.75 \mathrm{~g}$ and $6.35 \%$, respectively.

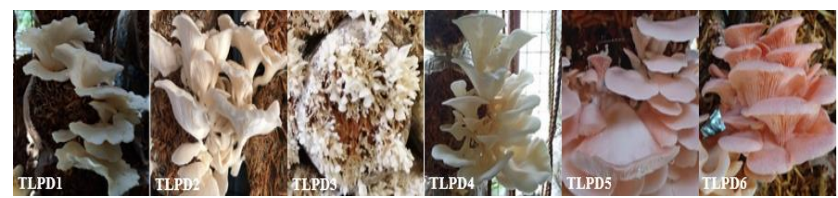

Figure-2: Cultivated fruiting bodies of Pleurotus djamor on rice straw and sawdust-based substrate in growing house condition.

\section{Discussion}

The culture medium is any nutrient material prepared for the cultivation of desired microorganisms. It contains carbon source, nitrogen source, vitamins and minerals which are essential for the normal growth and development. Different culture media contains specific kinds and amount of nutrients. In the present study, several laboratory-made and commercial semisynthetic media were evaluated. Variation in the mycelial growth response of six strains of $P$. djamor was observed in various culture media evaluated. This could be attributed to specific nutrient requirements of the strain and the nutrients present in the media. The findings of the present study strongly suggest that variation in mycelial growth response does not only exist between species but also between strains of mushroom. This agrees with the observation of Gabriel et al. (2018) that each strain of Lyophyllum requires a different medium to favor its development. In a similar study, Vilas et al. (2020) disclosed that eleven isolates of Pleurotus spp. showed significant growth on malt extract agar followed by potato dextrose agar. Yadav and Chandra (2014) noticed fast and full growth of three strains of Agaricus bisporus on potato dextrose agar. However, Kalaw et al. (2016) reported differences in incubation period of different strains of Volvariella volvacea on various indigenous culture media. Several studies have also confirmed that different mushroom species require specific medium for the rapidity of mycelial growth. For instance, Auricularia polytricha, Lentinus squarrosulus and Polyporus grammocephalus preferred coconut water gulaman (De Leon et al., 2013; Zurbano, 2017) while potato dextrose agar is found to be the most suitable culture medium for Pleurotus floridanus, Auricularia auricula-judae and Pleurotus species (Ishaq et al., 2017; Jo et al., 2014; Sardar et al., 2015). However, sabouraud dextrose agar and coconut water agar are found to be the most suitable for Lentinus strigosus (Dulay and Gracia, 2017). In addition, Nasim et al. (2001) reported that mycelia of Pleurotus ostreatus var. sajor caju, Pleurotus ostreatus var, cystidiosus and Volvariella volvacea favorably grew on malt extract agar.

The $\mathrm{pH}$ of the medium can influence the growth and morphology of fungi either directly by its action on the cell exterior or indirectly by its effect on the availability of nutrients (Gibbs et al., 2000; Abubakar 
et al., 2013). Results obtained in the present study indicate that each strain has specific $\mathrm{pH}$ for optimum mycelial growth. These findings confirm the general observation that the $\mathrm{pH}$ requirement of mushrooms varies from species to species and strain to strain. These observations strongly indicate that $\mathrm{pH}$ is not only species specific but also strain dependent. The above-mentioned findings agree with the report of Imtiaj et al. (2008) that the most suitable $\mathrm{pH}$ favorable for different stains Hericium erenacius was observed in the range of 5 to 9 . Moreover, Sardar et al. (2015) revealed that the maximum growth of different strains of Pleurotus was observed in $\mathrm{pH} 6$ whereas the minimum growth was recorded at $\mathrm{pH} 4$. Several studies have also confirmed that some mushroom species can grow in a wide range of $\mathrm{pH}$. For example, Korean wild strains of Ganoderma lucidum can grow at $\mathrm{pH} 5$ to 7 (Jayasinghe et al., 2008), Pleurotus ostreatus and Pleurotus giganteus, Lentinus conatus and Lentinus roseus at $\mathrm{pH} 5.0$ to 8.0 (Klumklong et al., 2014). However, some mushroom species can grow in a narrow range of $\mathrm{pH}$ such as Paneolus antillarium and Paneolus cyanescens which efficiently grow at $\mathrm{pH}$ of 7.5 to 8 (Bustillos et al., 2014).

Mushrooms require aerobic condition. Hence, sufficient supply of oxygen promotes mycelial growth (Chang and Miles, 2004). In general, mushrooms consume $\mathrm{O}_{2}$ to secure the chemical energy needed for mycelial growth, and fruiting bodies then generate $\mathrm{CO}_{2}$ (Park et al. 2002 as cited by Lee et al., 2012). The different strains of $P$. djamor exhibited varied mycelial growth response to two aeration conditions. One strain exhibited faster mycelial growth in the presence of atmospheric air while the four strains can grow in the presence or absence of air. The findings of the present study support previous observations. For example, Tolentino (2016) reported that mycelial growth of Pleurotus sajor-caju, Pleurotus pulmonarius and Pleurotus florida significantly produced larger mycelial growth in sealed condition. Furthermore, Magday et al. (2014) noted that Ganoderma lucidum could also grow rapidly in sealed condition. However, Dulay et al. (2012) reported that air is not necessary for the mycelial growth of Lentinus tigrinus.

Although mushrooms are not photosynthetic, they need light to stimulate the mycelial growth and fruiting body production. It is an important factor for reproduction, metabolism and distribution for the survival of fungi (Cheng et al., 2012). It also acts as a signal triggering off various biophysical and biochemical processes ultimately leading to morphological and phototrophic reactions (Trukhonovets, 1991). In the natural habitat, mushrooms are exposed to alternating light and dark conditions. The data obtained in the present study indicate that the mycelial growth four strains of $P$. djamor were not affected by light while one strain exhibited faster mycelial growth in dark condition. This finding indicates that light requirement is not only species but also strain dependent. This agrees with previous reports regarding the mycelial growth response of different species of mushrooms to light. For instance, Pokhrel et al. (2009) reported that Agaricus blazei produced luxuriant mycelial growth in total lighted condition. However, Hypsizygus ulmarius and three strains of Lentinula edodes preferred absence of light (Jatav et al., 2012; Quaicoe et al., 2014). Furthermore, Daoping (2003) reported that dark condition is suitable for the efficient mycelial growth of Pleurotus eryngii and Pleurotus nebrodensis. Moreover, Laricifomes officinalis, Omphalotus olearius and Panellus stipticus showed rapid mycelial growth in total darkness (Zhu et al., 2011; Weitz et al., 2001). On the other hand, mycelial growth of Pleurotus djamor was not significantly affected by light and can grow either in lighted or dark condition (Bumanlag et al, 2018).

Temperature is used as the basis in selection of the species or strains of mushroom that are suitable in the area where the mushroom is being cultivated. It determines the distribution and proliferation of mushrooms. In the present study, it was noted that the mycelia of five strains of $P$. djamor grew luxuriantly at $30^{\circ} \mathrm{C}$ and $23^{\circ} \mathrm{C}$, however, no growth was recorded at $9^{\circ} \mathrm{C}$. These data confirm that the collected wild strains of mushrooms have a wide range of temperature requirement. These strains can be successfully cultivated in the tropical conditions of the Philippines. In a similar study, Neelam et al. (2013) reported that the optimum temperature for mycelial growth of Pleurotus florida is 28 to $30^{\circ} \mathrm{C}$. Sardar et al. (2015) concluded that 20 to $25^{\circ} \mathrm{C}$ appears to be the universal temperature range for mycelial growth of mushrooms. On the other hand, Zharare et al. (2010) reported that the maximal mycelial growth of Pleurotus is found at 25 to 30 , while $35^{\circ} \mathrm{C}$ is detrimental to mycelial growth. The absence of mycelial growth at $9^{\circ} \mathrm{C}$ implies that the mycelia of $P$. djamor is inhibited by this temperature. 
This finding agrees with Lee et al. (2008) who reported that G. lucidum appeared to be significantly inhibited at $9^{\circ} \mathrm{C}$ due to the denaturation and inactivation of important enzymes which catalyze metabolic processes.

In our desire to select the best strain in terms of yield and other parameters, we evaluated the performance of six strains of $P$. djamor on rice straw and sawdustbased substrate formulation. Significant variation in mycelial growth (incubation period and initiation of primordia) and fruiting body performance (cap diameter, stipe length, yield and biological efficiency) of the different strains were recorded. This finding is congruent to early reports that genetic variation does not only exist between species but also within species of mushrooms. This observation may be due to the difference in the genetic make-up of the different strains. For instance, Villaceran et al. (2006) reported the difference in the performance of Thai and Japanese strains of Pleurotus sajor-caju cultured on Vovariella mushroom spent and composted rice straw. Moreover, several researchers also observed strain variation in different species of mushrooms such as Pleurotus eryngii (Moonmoon et al., 2010), Pleurotus ostreatus and Pleurotus pulmonarius (Myronycheva et al., 2017), Pleurotus geesteranus (Ahmed et al. 2013), Pleurotus spp (Shroff, 2019; Kumar and Kushwaha, 2014). In summary, different wild strains of $P$. djamor showed varied response to different nutritional and physical factors. Some strains can produce low yield and some can produce higher yield.

\section{Conclusion}

In conclusion, this work has established the optimal mycelial growth conditions with special reference to the nutritional and physical requirements and cultivation potentials using rice straw and sawdustbased substrate of six wild strains of $P$. djamor. Different strains demonstrated varied performance in the different cultivation parameters. Comparing the biological efficiencies of the six $P$. djamor strains with commercially cultivated mushrooms, values obtained in the present study are far low. In order to improve these parameters, supplementation of the substrates using nutritious additives such as rice bran, corn bran or wheat bran should be considered in our future research undertakings.

\section{Acknowledgement}

The authors are very grateful to the Philippine Council for Health Research and Development, Department of Science and Technology for the fund support.

Disclaimer: None.

Conflict of Interest: None.

Source of Funding: Philippine Council for Health Research and Development, Department of Science and Technology.

\section{References}

Abubakar A, Suberu HA, Bello IM, Abdulkadir R, Daudu OA and Lateef AA, 2013. Effect of the $\mathrm{pH}$ on mycelial growth and sporulation as Aspergillus parasiticus. J. Plant Sci. 1(4): 64-67.

Ahmed M, Abdullah N, Ahmed KU and Bhuyan MHMA, 2013. Yield a nd nutritional composition of oyster mushroom strains newly introduced in Bangladesh. Pesqui Agropecu Bras. 48(2): 197-202.

Bumanlag CPB, Kalaw SP, Dulay RMR and Reyes $\mathrm{RG}$, 2018. Optimum conditions for mycelia growth and basidiocarps production of Pleurotus djamor on corn-based media. Int. J. Biol. Pharm. Allied Sci. 7(4): 558-575.

Bustillos RG, Dulay RMR, Kalaw SP and Reyes RG, 2014. Optimization of culture conditions for mycelial growth and basidiocarp production of Philippine strains of Panaeolus antillarium and Panaeolus cyanescens. Mycosphere. 5(3): 398404.

Chang ST and Miles PG, 2004. Mushroom cultivation, nutritive value, medicinal effect and environmental impact. $2^{\text {nd }}$ ed. USA, CRC Press. 477.

Cheng CW, Chen CK, Chang CJ and Chen LY, 2012. Effect of colour LEDs on mycelial growth of Aspergillus ficuum and phytase production in photo-fermentation. J. Photochem. Photobiol. 106: 81-85.

Daoping G, 2003. Research on mycelia protection enzymatic charge under different $\mathrm{pH}$ conditions. Edible Fungi. 20: 6-8.

De Leon AM, Reyes RG and De La Cruz TEE, 2013. Lentinus squarrosulus and Polyporus grammocephalus: Newly domesticated, wild edible macrofungi from the Philippines. Philipp Agric Sci 96(4): 411-418. 
Dulay RMR, Kalaw SP, Reyes RG, Cabrera RC and Alfonso NF, 2012. Optimization of culture conditions for mycelial growth and basidiocarps production of Lentinus tigrinus (Bull.) Fr., a new record of domesticated wild edible mushroom in the Philippines. Philipp. Agric. Sci. 95(3): 278285.

Dulay RMR and Gracia EJB, 2017. Optimization and enriched cultivation of Philippine (CLSU) strain of Lentinus strigosus (BIL 1324). Biocatal. Agric. Biotechnol. 10: 242-246.

Gabriel YA, Aguilar CB, Orijel CB, Ferrer NM, Maass SF and Mata G, 2018. Genetic characterization, evaluation of growth and production of biomass of strains from wild edible mushrooms of Lyophyllum of Central Mexico. Braz. J. Microbiol. 40(3): 632-640.

Gibbs PA, Seviour RJ and Schmidt F, 2000. Growth of filamentous fungi in submerged culture: Problems and possible solutions. Crit. Rev. Biotechnol. 20(1): 17 - 48 .

Jatav RS, Gupta AK, Doshi A and Meemna AK, 2012. Studies of different physical factors on mycelial growth of blue oyster mushroom Hypsizygus ulmarius (Bull.). Int. J. Agric. Stat. Sci. 8(1): 347-354.

Jayasinghe C, Imtiaj A, Hur H, Lee GW, Lee TS and Lee UY, 2008. Favorable culture conditions for mycelial growth of Korean wild strains of Ganoderma lucidum. Mycobiol. 36(1): 28-33.

Imtiaj A, Jayasinghe C, Lee GW and Lee TS, 2008. Comparative study of environments and nutritional factors on mycelial growth of edible mushrooms. J. Cult. Collect. 6: 97-105.

Ishaq M, Fiaz M, Saifullah, Ullah S and Khan MB, 2017. Evaluation of mycelial growth of oyster mushroom (Pleurotus floridanus Singer) on different media and cereal grains. J. Biodivers. Environ. Sci. 11(3): 67-72

Jo WS, Kim DG, Seok SJ, Jung HY and Park SC, 2014. The culture conditions for the mycelial growth of Auricularia auricula-judae. J. Mushrooms. 12(2): 88-95.

Kalaw SP, Alfonso DO, Dulay RMR, De Leon AM, Undan JQ, Undan JR and Reyes RG, 2016. Optimization of culture conditions for secondary mycelial growth of wild macrofungi from selected areas in Central Luzon, Philippines. Curr. Res. Environ. Appl. Mycol. 6(4): 277-287.

Klumklong N, Karunarathna SC, Hyde KD and Chukeatirote E, 2014. Optimal conditions of mycelial growth of three wild edible mushrooms from Northern Thailand. ACTA Biol. Szeged. 58(1): 39-43.

Kumar R and Kushwaha KPS, 2014. Evaluation of different strains of oyster mushroom from their cultural, morphological and yield attributes. Proc. $8^{\text {th }}$ International Conference on Mushroom Biology and Mushroom Products.

Lee UY, Jayasinghe C, Imtiaj A, Hur H, Lee GW and Lee TS, 2008. Favorable culture conditions for mycelial growth of Korean wild strains in Ganoderma lucidum. Mycobiol. 36: 28-33.

Lee, HY, Ham EJ, Yoo YJ, Kim ES, Shim KK, Kim MY and Koo CD, 2012. Effects of aeration on sawdust cultivation bags on hyphal growth of Lentinula edodes. Mycobiol. 4(3): 164-167.

Li CH, Chen PY, Chang UM, Kan LS, WH Fang, Tsai KS and Lin SB 2005. Ganoderic acid X, alanostanoid triterpene, inhibits topoisomerases and induces apoptosis of cancer cells. Life Sci. 77(3): 252-265.

Magday Jr. JC, Bungihan ME and Dulay RMR, 2014. Optimization of mycelial growth and cultivation of fruiting body of Philippine wild strain of Ganoderma lucidum. Curr. Res. Environ. Appl. Mycol. 4(2): 162-172.

Maity GN, Maity P, Khatua S, Acharya K, Dalai S and Mondal S, 2021. Structural features and antioxidant activity of a new galactoglucan from edible mushroom Pleurotus djamour. Int. J. Biol. Mol. 168: 743-749.

Moonmoon M, Uddin MN, Ahmed S, Shelley NJ and Khan MA, 2010. Cultivation of different strains of king oyster mushroom (Pleurotus eryngii) on sawdust and rice straw in Bangladesh. Saudi J. Biol. Sci. 17(4): 341-345.

Myronycheva O, Bandura I, Bisko N, Gryganskyi AP and Karlsson O, 2017. Assessment of the growth and fruiting of 19 oyster mushroom strains for indoor cultivation on lignocellulosic wastes. Bioresources. 12(3): 4606-4626.

Nasim G, Shahid M, Bajwa R, Afzal M and Salman M, 2001. Effect of three different culture media on mycelial growth of oyster and Chinese mushrooms. Journal of Biological Sciences. 1: 1130-1133.

Neelam S, Chennupati S and Singh S, 2013. Comparative studies on growth parameters and physio-chemical analysis of Pleurotus ostreatus and Pleurotus florida. Asian J. Plant Sci. Res. 3: 163-169. 
Park JP, Kim SW, Hwang HJ, Cho YJ and Yun JW, 2002. Stimulatory effect of plant oils and fatty acids on the exobiopolymer production in Cordyceps militaris. Enzym. Microb. Technol. 31: 250-55.

Pineda-Alegria JA, Sanchez-Vasquez JE, GonzalesCortazar M, Zamilipa A, Lopez_Arellano M, Cuevas-Padilla EJ, Mendoza-de-Gives $\mathrm{P}$ and Aguilar-Marcelino L, 2017. The edible mushroom Pleurotus djamour produces metabolites with lethal activity against the parasitic nematode Heamonchus contortus. J. Med. Food. 12: 1184-1192.

Pokhrel CP, Yadav RKP and Ohga S, 2009. Effects of physical factors and synthetic media on mycelial growth of Lyophyllum decastes. J. Ecobiotechnol. 1(1): 046-050

Quaicoe EH, Amoah C, Obodai M and GT Odamtten $\mathrm{G}$, 2014. Nutrient requirements and environmental conditions for the cultivation of the medicinal mushroom (Lentinula edodes) (Berk) in Ghana. Int. J. Sci. Technol. Res. 3(12): 45-50.

Ragasa CY, Tan MCS, Ting J, Reyes RG, Brkjaca R and Urban S, 2016. Chemical constituents of Pleurotus djamour. Der. Pharma. Chem. 8(2): 343-346.

Reyes RG, Eguchi F, Kalaw SP and Kikukawa T, 2009. Mushroom Growing in the Tropics: A Practical Guide, Nueva Ecija, Philippines, Central Luzon State University Press.

Sardar H, Ali MA, Ayyub CM and Ahmad R, 2015. Effect of different culture media, $\mathrm{pH}$ and temperature on the growth of wild and exotic Pleurotus species. Pak. J. Phytopathol. 27(2): 139-145.

Sasidhara R and Thirunalasundari T, 2014. Phytochemicals and antioxidant potentials of Pleurotus djamour. J. Chem. Pharm. Res. 6(4): 950-953.

Shroff S, 2019. Evaluation of high yielding strains of oyster mushroom (Pleurotus spp). Int. J. Curr. Microbiol. Appl. Sci. 8(6): 1054-1060.

Tang X, Mi F, Zhang Y, He X, Cao Y and Wang P, 2015. Diversity, population genetics and evolution of macrofungi associated with animals. Mycol. 6(2): 94-109.

Torres ML, Tadiosa ER and Reyes RG, 2020. Species listing of macrofungi on the Bugkalot tribal community in Alfonso Castaneda, Nueva
Vizcaya, Philippines. Curr. Res. Environ. Appl. Mycol. 10(1): 475-493.

Tolentino JV, 2016. Growth performance and proximate nutrient composition of Pleurotus species on corn-based substrate. MS Thesis. Central Luzon State University, Science City of Muñoz, Nueva Ecija.

Trukhonovets VV, 1991. Effect of illumination intensity on the formation of fruiting bodies in Pleurotus ostreatus (Jacq. Fr.) Kumm. Ukr. J. Bot. 48(2): 67-72.

Vilas PM, Jadhav AC, Dhavale MC, Hasabnis SN, Gaikwad AP, Jhadav PR and Ajit PS, 2020. Effect of cultural variability on mycelial growth of eleven mushroom isolates of Plerotus spp. J. Pharmacogn. Phytochem. 9(6): 881-888.

Villaceran AB Jr., Kalaw SP, Nitural PS, Abella EA and Reyes RG, 2006. Cultivation of Thai and Japanese strains of Pleurotus- sajor caju on rice straw based Volvariella volvacea mushroom spent and composted rice straw in Central Luzon Region, Philippines. J. Agric. Technol. 2(1): 6975.

Weitz HJ, Ballard AL, Campbell CD and Killham K, 2001. The effect of culture conditions on the mycelial growth and luminescence of naturally bioluminescent fungi. FEMS Microbiol. Lett. 202(2): 165-170.

Yadav MK and Chandra R, 2014. Effect of culture media, $\mathrm{pH}$ and temperature on mycelial growth of Agaricus bisporus strains. J. Pure Appl. Microbiol. 8(3): 1-5.

Zhang M, Zhang Y, Zhang L and Tian Q, 2019. Mushroom polysaccharide lentinan for treating different types of cancers: A review of 12 years clinical studies in China. Prog. Mol. Biol. Transl. Sci. 163: 297-328.

Zharare GE, Kabanda SM and Poku JZ, 2010. Effects of temperature and hydrogen peroxide on mycelial growth of eight Pleurotus strains. Sci. Hortic. 125(2): 95-102.

Zhou B, Fu Q, Song SS, Zheng HL and Wei YZ, 2015. Inhibitory effect of schizophyllan on rat glioma cells. Bangladesh J. Pharmacol. 10: 759 764.

Zhu NL, Shan H and Guo H, 2011. The study of Laricifomes officinalis optimization of solid medium and establish of culture conditions. Anhui Agric. Sci. Bull. 1(2): 67-80.

Zurbano LY, 2017. Mycelial growth and fructification of Auricularia polytricha on 
different substrates. PUP J. Sci. Technol. 10: 1908-9058.

\section{Contribution of Authors}

Kalaw SP, Dulay RMR, De Leon AM, Reyes RG: Conceptualization of the study, literature review search, research design and methodology assessment, experimental design and data interpretation, manuscript writing and critiquing, final approval.

Damaso Jr. EJ, Ramos JC, del Rosario MAG, Abon MD: Experimentation, data collection, statistical analysis and interpretation. 